The Research Journal of the Costume Culture

[Original Article]
Received April 23, 2017

Revised June 09, 2017

Accepted June 12, 2017

${ }^{\dagger}$ Corresponding author (cej1214@ysu.ac.kr)

ORCID

Eunjoo Choi

http://orcid.org/0000-0002-0854-4980

The project of supporting the research fund of Youngsan University in 2016.
pISSN 1226-0401

RJCC Vol.25, No.3, pp.340-358, June 2017

https://doi.org/10.7741/rjcc. 2017.25.3.340

\section{A study on the vest shape and tailoring of the Korean Empire in the 1900s}

\author{
Eunjoo $\mathrm{Choi}^{\dagger}$
}

Dept. of Fashion Design, Youngsan University, Korea

\begin{abstract}
The purpose of this study is to fundamentally examine the vests of the robes "Daeraebok" and "Soraebok" of the Korean Empire from the 1876 Port Opening to the 1910 annexation of Korea to Japan. Among the collections of different robes of the Korean Empire which belong to various universities and institutions, only the vests were surveyed. The shape of the vests in the Korean Empire were single-breasted and doublebreasted. Most V-necklines and vests with a shawl collar look like a tailored collar, where the collar outline was shaped like a notched and picked collar, which is a mix of the step collar and roll collar of the 19th century. The rear center line was not flat, but inclined to a triangle. All vests of the robe Daeraebok were equipped with gold buttons, and those of the robe Soraebok had black satin buttons. The tailoring characteristic is that the front has a different material (dark black wool) from the back (black silk). This characteristic is expected to be an important basic piece of information in the restoration and reproduction of the vest, which was worn during the imperial period, especially to reveal its shape, characteristics and composition. This characteristic can also be used as data of cultural contents based on Korean modern history.
\end{abstract}

Keywords: vests(조끼), Daeraebok(대례복), Soraebok(소례복), Korean Empire (대한제국기)

\section{Introduction}

우리나라의 개항은 $19 \mathrm{C}$ 에 외부의 강압에 의해 되어졌으며, 한국의 근 - 현대 복 식사에서 개화기는 최초의 개항시기에 맞추어 1876년 강화도 수호조약 체결부터 한일합방이 이루어진 1910년까지로 시대를 구분하고 있다(Ryu, 1980). 강화도 조 약 체결 후 본격적으로 외래 문물을 도입하기 시작하면서 근대 신문화가 소개되었 고, 이 시기에 복식제도 역시 많은 영향을 받아 급격하게 변화하게 되었다(Culture Heritage Administration, 2012). 이 무렵 우리나라는 고종의 연호를 건양(建陽)에서 
광무(光武)로 고치고, 1897년 10월 12일부터 1910년 8 월 29일까지 국호를 대한제국으로 자주적인 개혁을 진행하여 대한이 자주독립국가임을 대내외에 거듭 재 천명하고, 자주독립의 강화를 국내와 세계에 알린 대 한제국기의 역사적인 시기를 보내었다(Kim, 1987; Lee, 1999).

2012 근현대문화유산 의생활분야 목록화 조사 보 고서(Culture Heritage Administration, 2012)에서 '개 항기 남자 복식에 있어서 전통한복에서 양복으로 바 뀌게 된 것은 1894 년 갑오의제개혁, 1895 년 단발령, 고종의 실크 햇(silk hat), 프록코트(frock coat)의 착용 과 순종이 70 여명의 신하와 더불어 양복차림으로 지 방을 시찰한 것이 획기적인 전환점을 가져왔다고 할 수 있다'고 하는 것처럼 복식의 변천에 있어서 대한 제국은 이 때부터 광무개혁이 진행되었으며, 관복에 있어서 양복도입은 이 시기에 이루어지게 되었다.

1899년 8월 외교관의 복장에 양복이 도입되고, 광 무 4년 1900년 4월 17일 발표한 칙령에서는 문관의 대례복, 소례복, 상복을 서양식 관복으로 제정하였다. 이처럼 서양식 관복(대 - 소례복)은 1900 년에 제정되 어 한일합방이 이루어지는 1910년까지 존속하였다

1900년 4월 17일 칙령 제14호 “문관복장규칙”과 칙령 제 15 호 “문관대례복제식“을 발표하였고, 1904년 과 1905년, 1907년에 걸쳐 관보(官報)에 ‘정오(正誤)' 의 형식으로 수정되었다(Korean Empire Ministry Record Section, 1908/1982). 최종적으로 개정된 문관복 장 규칙은 1908년 “법규류편(法規類編)”에 총 12조와 부칙1조로 되어 있다.

개항기 복식에 관한 선행연구들은 Kim(1977)의 개 화기 문관복에 대한 연구, $\operatorname{Kim}(1987)$ 의 개화기 양복 도입과 수용과정 등에 관한 연구, Lee and Kim(1995) 의 우리나라 양복수용과정의 복식변천에 대한 연구, Hwang(2000)의 개화기 한국복식의 변천, Park(2003) 의 개화기 복식의 변천, Lee(1984)의 개화기 복식의 변천과 그 요인, Lee and Lee(2000)의 19세기 개항이 후 한 - 일 복식제도 비교 등이 있다. 대한제국기 복 식에 관한 선행연구들은 Lee(2008)의 대한제국의 서 구식 대례복 패러다임, Choi(2011)의 1905 1906 서 구식 대례복제도 개정에 나타난 일제의 한국병탄 준 비, Choi(2008)의 대한제국기 궁내부 대례복 연구, Choi(2012)의 대한제국시대 관원의 예복, Lee(2010)
의 대한제국 1900년(광무4) 문관 대례복 제도와 무궁 화 문양의 상징성, Lee(2011)의 대한제국기 서구식 문관대례복 제도의 개정과 국가정체성 상실 등으로 주로 대례복과 양복수용, 복식변천 등에 관한 연구 및 분석이 이루어지고 있다.

이 시기의 복식의 제작법에 관한 연구는 Lee(2013) 의 대한제국기 문관 대례복 제작에 관한 연구, Choi (2015)의 대한제국기 프록코트 형태 및 제작법에 관 한 연구 등으로 관련 연구가 적으며, 대한제국기 당 시의 대례복, 소례복, 통상복 등의 일습으로 구성되어 입혀졌던 조끼에 관한 독립적인 연구는 미흡하였다. 그 러므로 본 연구에서는 선행연구 대한제국기 프로코 트의 형태 및 제작법에 관한 연구에 이어 대한제국기 의 대례복과 소례복에 착용되었던 남성조끼의 형태 및 제작법에 대해 조사 및 고찰하고자 하였다.

대한제국기 당시에 착용된 남자 조끼 유물의 경우, '문화재청 의생활분야 목록화 조사보고서(Culture Heritage Administration, 2012)'에 의하면 대례복의 일습으로 5점, 소례복의 일습으로 1점이 등록되어 있 고, 조사보고서에 포함되어 있지 않은 부산시립박물 관 소장의 박기종의 대 - 소례복 유물 중 2점이 조사 되었다. Lee(2013)가 밝히고 있는 것처럼 대한제국기 의 유물들이 100 년 이상의 시간이 경과되어 자연스러 운 과정으로, 보관의 상태에 따라 낡아지고 있으므로 본 연구에서는 착용시기가 명확한 기증유물 중 서양 식 관복에 속하는 조끼의 실물계측 및 사진 보고서를 연구대상으로 삼고, 형태 특성과 테일러링에 대해 유 물을 중심으로 실증적 고찰을 하고자 한다.

차후 우리나라 남성복 변천사에 있어서 대한제국기 당시 서구식 양복으로 대례복과 소례복, 통상복으로 착용되었던 서구식 양복 중 남성조끼의 복원이나 재 현 등이 필요할 때, 조끼의 형태적 특성과 테일러링, 도식화 등이 기초자료로 활용될 수 있을 것으로 사료 된다.

\section{Background}

\section{The process of western costume adoption}

개항이후 우리나라는 전반적인 의제개혁이 이루어 지기전에 신식군대의 군인과 외교사절 및 유학생에 의하여 양복이 착용되었다. 갑신(甲申 1884), 갑오(甲 
午 1894), 을미(乙未 1895)의제개혁을 통하여 기존복 식을 흑단령, 두루마기로 간소화하고, 형식상에 있어서 대례복, 소례복 통상복 제도를 도입하였으며, 1895년 에 단발령을 발표하고 대한제국의 의제개혁(1900)을 통하여 양복을 도입하였다(Kum et al., 2002). Ryu (1989)는 개항 이후 우리나라의 복식제도를 통일신라 이후 계속된 중국복식과의 이중구조로부터 서양복식 와의 이중구조로 바뀐 것으로 보았다. 양복수용과정 의 유행선도자로는 유학생, 외교관, 신식교육기관의 학생, 전도부인, 군인, 정부관리들이었다고 볼 수 있 다(Lee \& Kim, 1995).

양복 수용에 있어서 가장 대표적으로 기록과 유물로 남아있는 서양식 관복은 1900년부터 1908년에 걸쳐 변화되어온 문관의 관복으로 다음과 같다.

대례복은 대례모, 대례의, 조끼, 대례고, 검, 검대, 백 색칼라, 백색장갑으로 구성되고, 영국의 궁중 예복을 모방한 일본의 대례복을 참작한 것으로 궁궐에서 황 제를 알현하는 상황에 착용하였다. 소례복인 프록코 트와 연미복은 유럽제국에서 사용되던 시민의 예복 으로 진사고모(silk top hat), 구제연미복 또는 프록코 트, 조끼, 바지로 구성되고, 연미복은 각국 사신 소접 시, 궁중 사연 시, 국외국 관인 만찬 시에 착용하고 프록코트는 궁내진현시, 각국 경절 하례 시, 사적인 하례와 예방 시에 착용하였다. 상복은 서양에서 착용 되던 시민의 평복인 세비로(sack coat)와 같은 것으로 구미평모(중절모자), 구제통상의, 조끼, 바지로 구성 되고, 임시로 진현할 때, 연거할 때, 집무할 때 착용하 도록 규정되었다(Ryu, 1989).

\section{Vest}

조끼는 국어사전에서 '배자(袙子)와 같이 생긴 것으 로, 한복에는 저고리나 적삼 위에, 양복에는 셔츠 위 에 덧입는, 소매가 없는 옷. 흔히 호주머니가 달려 있 다.’라고 풀이되어 있고(“Vest”, n.d.), 한국복식문화 사전(Kim, 1999)에서 조끼는 '저고리 위에 덧입는 소 매 없는 옷으로, 개화기부터 현재까지 사용되고 있으 며, 겹조끼와 홑조끼 2종류가 있다.'라고 되어 있다. 패 션 전문 자료사전(Fashion Text Dictionary Committee, 1999)에서 조끼는 '저고리 위에 입는 조끼는 저고리 의 모양을 돋보이게 할 뿐만 아니라 호주머니가 있어 편하고 방한용으로도 효과가 있어, 오늘날에는 한복

뿐만 아니라, 양복에서도 매우 중요한 위치를 차지하 고 있다'라고 되어 있다.

조끼는 미국에서 베스트(vest)라고 불렸으며, 엄격 한 의미에서 소매 없고 몸에 꼭 맞는 길이가 짧은 웃 옷을 말하며, 영국에서는 웨이스트코트(waistcoat)라 고 부르는 경우가 많다. 프랑스에서는 질레(Gilet)이라 고 부르며, 베스트(veste)라고 하는 경우에는 보다 의 미가 넓어 주로 몸에 꼭 끼는 옷이나 유니폼에 속하 는 것을 가리키는 경우가 많다. 일본에서는 조끼라고 부르며, 베스트를 나타내는 말로는 직착(直着), 직의 (直依), 동착(胴着)과 같은 말을 사용하고 있다. 초기 에는 좁은 소매가 달린 무릎길이의 긴 옷을 말했으나, 1840 년 무렵에 현재와 같은 형태가 되었다(Lee, 1996).

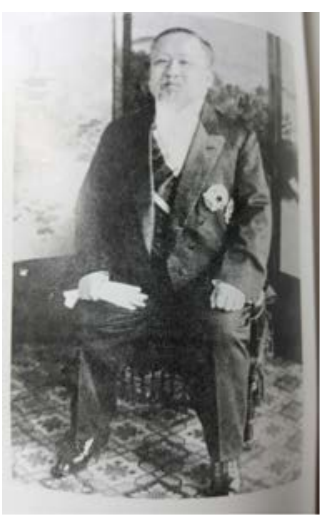

<Fig. 1> Ko-Jong's frock coat \& vest From. Kum et al. (2002). p. 52 .

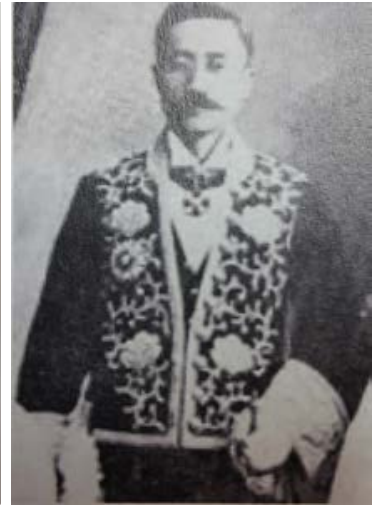

<Fig. 2> Yun Ci-Ho From. Kyungwoon Museum. (2012). p. 140.

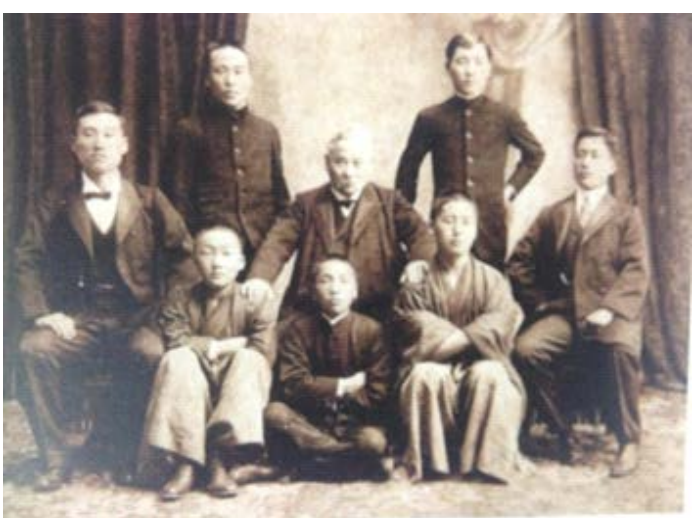

<Fig. 3> Park Ki-Jong \& his friends From. National Place Museum of Korea. (2010). p. 167. 


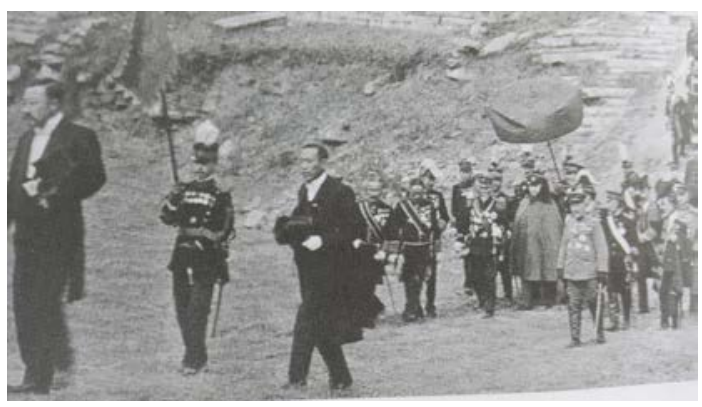

<Fig. 4> Sun-Jong's frock coat \& vest From. Kum et al. (2002). p. 10.

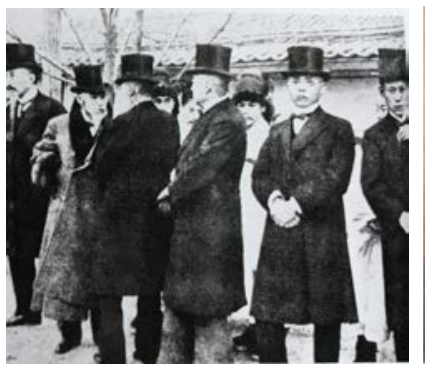

<Fig. 5> High office's frock coat \& vest

From. Kum et al. (2002). p. 76.

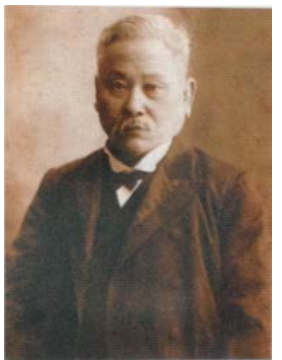

<Fig. 6> Park Ki-Jong From. Kim. (2005). p. 73.
조끼는 원래 군복 착용 시 호신용 복장이었으나, 시 간이 흐르면서 차츰 일반 시민들에게로 확산되었으 며, 우리나라는 갑오경장 이후 서구에서 수입하여 점 차적으로 형태의 변화를 거듭하여 왔다(Choi, 1995).

1830 1850년 동안 조끼는 매우 단품적인 의복으로 남자의 겉옷 중 가장 작지만 매우 멋진 소재로 두드 러지게 되어졌다. 질감과 색상이 풍부하고 패턴과 디 자인이 다양한 소재는 매우 비싸므로 앞길에만 사용 되고, 뒷길은 보통 앞길보다 못한 재질의 소재를 사 용하였는데, 이러한 제작방법은 오늘날까지 계속되어 지고 있다. 롤칼라(roll collar)는 이 시기 동안 인기 있었으며, 싱글브레스트와 더블브레스트 스타일 모두 입혀졌는데, 싱글브레스트 스타일이 더 대중적이었다.

1850 과 1860 년대의 조끼는 바지와 매치하는 추세 였으며, 지난 10 년 동안의 더 뛰어난 직물은 체크와 줄무늬 등으로 대체되었다. 이러한 조끼를 매칭 베스 트(matching vest)라 불렀다. 그리고 싱글과 더블브레 스트 두 스타일은 롤칼라가 추가된 것이 대중적이었 는데, 이것은 칼라와 라펠이 하나로 결합되고, 조끼와
따로 만들어 앞 V-zone 부분에만 놓이고, 뒷목둘레까 지 둘러지지 않고 어깨솔기에서 봉제되는 것으로 스 텝 칼라(step collar)로 알려졌었다. 이러한 스타일은 19세기 끝까지 계속되었다.

1860년대 이후 조끼는 단품이기 보다 코트와 바지 와 함께 합쳐진 옷으로써 모두 같은 소재로 쓰리피스 슈트(three piece suit)로 형성되었다. 그러나 조끼는 대비되는 소재로 계속 만들어져 이브닝드레스코트와 더블브레스트 프록코트와 함께 입혀졌다(Davis, 1994).

1870년대에 쓰리피스 슈트라는 복장이 정착됨으로 써 조끼는 신사복에서 빼놓을 수 없는 아이템으로 자 리 잡게 되었다(Lee, 1996). 1890년대 더블브레스트 웨이스트코트는 칼라와 리버스(revers)부분이 있는 스 타일로 단추 4개씩 2줄로 여며져 있고, 웰트 포켓 (welt pocket)이 가슴과 허리 좌우에 모두 있는 형태 이다(Davis, 1994).

대한제국 당시 대례복과 소례복인 프록코트와 연 미복, 통상복인 세빌로는 모두 겉옷인 재킷과 셔츠, 조끼, 바지, 모자, 구두 등으로 일습을 갖추고 있으며, 조끼는 대부분 겉옷인 재킷과 같은 소재로 제작되어 져 있었다. 〈Fig. 1〉 〈Fig. 6>과 같이 대한제국기 당시 사진에서 사진 속 인물들이 대부분 프록코트와 대례 복 안에 조끼를 함께 착용하고 있는 것을 볼 수 있으 며, 당시 양복을 착용한 사람들은 대부분 조끼가 갖 추어진 일습으로 착용하고 있었을 것으로 추측할 수 있다.

\section{Method}

본 연구에서는 여러 대학과 기관의 박물관에서 소 장하고 있는 유물 중 대한제국기 시기에 대례복, 소 례복 또는 통상복으로 사용되었던 남성복 일습 중에 서 조끼만 따로 고찰하여 양복 도입기 당시의 조끼 형태와 특성파악 및 치수, 테일러링 등을 실증적 고 찰을 하여 대한제국기의 복식 복원 및 재현 등을 위 한 기초 자료를 제공하고자 하였다.

본 연구의 연구자료 대상은 다음과 같다.

고려대학교 박물관 소장의 착용자 미상의 1900년 제식 주임관 대례복, 한국자수박물관이 소장하는 민철 훈(1956 1925)의 1900년대 모닝코트 소례복과 1901년 대례복, 한국자수박물관이 소장하는 박기준의 1906 
1910년에 제작된 궁내부 주임관 대례복, 연세대학교 박물관 소장의 윤치호(1864 1945)의 1905 1906년 제 식의 대례복, 국립민속박물관 소장의 착용자 미상의 1906년 제식의 주임관 대례복의 일습에 포함되어 있 는 조끼 각 1 점들을 연구 자료로 삼았다. 그리고 부산 박물관이 소장하는 박기종(1839 1907)의 칙임관 2등 대례복과 소례복은 1900 1907년 사이에 착용하였던 의복으로 19 점의 의복이 함께 기증되어 조끼 2 점은 어느 조끼가 대례복의 일습인지, 소례복의 일습인지 구분되어 있지 않지만, 착용자가 명확하고 대· 소례 복의 착용시기가 대한제국기이며, 조끼의 소재가 소 례복과 동일하여 2점의 조끼 모두 연구자료 대상에 포함하였다. 이처럼 여러 박물관에서 소장하고 있는 대한제국기 당시에 착용되었던 유물 들 중 조끼만 따 로 연구 대상으로 삼았다.

유물 실측은 먼저 박기종 유물은 1차로 2012년 1월 에 의복구성학 전공자 전문인 2 명이 의복구성과 패턴 제작 시 필요한 부위를 중심으로 줄자를 이용하여 각 부위별 2회 이상 계측하고, 그 평균치를 사용하였으 며, 자료 고찰에 부족한 부분들은 2017년 3월에 추가 계측하였다. 나머지 6점의 유물은 2016년 11 12월에 계측 및 고찰을 하였으며 실물을 관찰할 수 없거나 일부분만 관찰 가능한 자료들은 박물관에서 기 발표 한 유물도록집의 사진자료로 고찰을 하거나 관찰 가능 한 부분까지만 조사하였다. 의복의 좌우 치수 중 오른 쪽 치수를 기준치수로 이용하였다. 그리고 이들 계측된 치수들을 근거로 도식화 작업을 하였다. 본문에서 출 처를 밝히지 않은 사진은 직접 촬영한 자료이다.

\section{N. Results and Discussion}

\section{The period of wearing}

고려대학교 박물관 소장의 1900년 제식 주임관 대 례복은 착용자가 미상이지만, 제식이 1900년이므로 대한제국기에 착용되었을 것으로 추측되어진다.

한국자수박물관이 소장하는 1900년대 모닝코트 소 례복과 1901년 대례복은 민철훈(1956 1925)이 착용 하던 것으로 민철훈은 1956 년 서울 출생으로 명성황 후의 친족이자 고위 관료인 민종묵의 장남으로 1896 년 중추원 의원, 1899 년 궁내부 특진관 등에서 일하였 다. 1900 년에는 독일과 이태리, 영국을 겸임하는 특
명전권공사로 임용되고, 칙임3등에 서임되었으며, 외 교관으로 근무하였다. 1901년 오스트리아 공사를 겸 임하였으며, 1904년 주미전권공사와 1905년 독일 특 명전권 공사 등을 역임하였고, 1925년 7월 1일 사망 하였다((“Min Chulhoon”, n.d.). 민철훈의 문관예복은 1901년 프랑스에서 제작된 것으로 1901 1905년 사 이의 외교관으로 근무할 당시에 착용하였을 것으로 짐작된다(Kyungwoon Museum, 2012).

한국자수박물관이 소장하는 또 다른 1906 1910년 제작한 궁내부 주임관 대례복은 박기준(1875 ?)이 착 용하던 것으로 1905 년에 궁내부 주임관을 역임하였 으며, 문화재청에서 분류한 대로 1906 1910년 사이 에 착용하였을 것으로 추측된다.

연세대학교 박물관 소장의 1905 1906년 제식의 대 례복은 윤치호(1864 1945)의 것으로 윤치호는 한말 개화파로 1898년 독립협회 회장, 1903년 천안 군수 등을 역임한 인물이다. 1920년 이후에는 친일 활동을 펼쳤다. 조선 말기에 일본 - 미국 등에 유학하여 교육 을 받았으며, 의정부 참의, 학부협판 등을 역임하였 다. 대한제국기에는 독립협회 회장, 대성학교 교장 등 을 지냈다("Yun Chiho", n.d.a). 1896년에는 민영환의 수행원으로 러시아 황제 니콜라이 2세의 대관식에 참 석하였다. 1905년 을사늑약이 강제로 체결되자 관직 을 사퇴한 뒤 1906년 장지연 · 윤효정 등과 대한 자강 회를 조직하였고, 회장으로 추대되어 국민의 자주 자 강 정신과 능력을 기르는 데 힘썼다. 대한제국의 개 혁, 민권 운동가 - 문신이자 외교관 · 언론인으로 1905 1906년 제식의 대례복은 그 당시에 착용하였던 것으 로 짐작되어진다("Yun Chiho", n.d.b).

국립민속박물관 소장의 1906년 제식의 주임관 대 례복은 착용자가 미상이지만, 1906년 제식으로 대한 제국기 당시 입혀졌던 것으로 추측된다.

부산박물관이 소장하는 박기종(1839 1907)은 일본 수신사 역관, 대한철도회사 설립자 등을 역임한 조선 말기의 사업가로 그의 생존시기, 활동시기와 복식사 의 변천 시기를 고려해볼 때, 박기종의 칙임관 2 등 대 례복과 프록코트 소례복은 1900 1907년 사이에 착용 하였던 의복으로 짐작된다(Kim, 2005). Kim(1990)이 1905년을 전후하여 프록코트가 선을 보였고, 1910년 경에는 프록코트에 실크해트와 스틱을 갖추어 개화 기 양복신사의 품위를 표현하였다고 하는 것을 고려 
해본다면 프록코트 소례복은 1905 1907년경에 주로 착용하였을 것으로 추정된다(Busan Modern History Museum, 2005).

이상의 8점의 조끼들은 모두 1900 1907년 사이에 착용되었던 대한제국기 당시의 남성 조끼임을 알 수 있다.

\section{Vest manufacturer}

대부분은 조끼는 대례복 또는 소례복과 함께 일습 으로 제작되어 따로 조끼에 상표가 부착되어 있지 않 고, 대례복이나 소례복의 상의 재킷에 부착된 상표에 따르면 고려대 1900년 주임관 대례복은 러시아 L. Mihelson/St. Petersburg, 윤치호 대례복은 러시아, 민 철훈 대례복은 프랑스로 'Jules Maria/1901.6.10.Paris' 라는 라벨이 허리벨트 안쪽에 부착되어 있다(Fig. 7). 박기종 소례복은 프록코트형으로 ASADA TAILOR/ 경성이라는 라벨이 부착되어 있으며(Fig. 7), 박기준 대례복은 프록코트형 대례의로 소장자 면담에 의해 일본이라고 기록되어 있다. 그 밖의 국립민속박물관 1905년 주임관 대례복, 민철훈의 모닝코트 소례복과 박기종의 대례복은 라벨 미부착 또는 밀납인형 등에 착장형식으로 보관 및 전시되어 유물 조사의 어려움 등의 이유로 제작처가 밝혀져 있지 않다. 박기종의 ASADA TAILOR는 경성이라는 글자를 고려해 볼 때
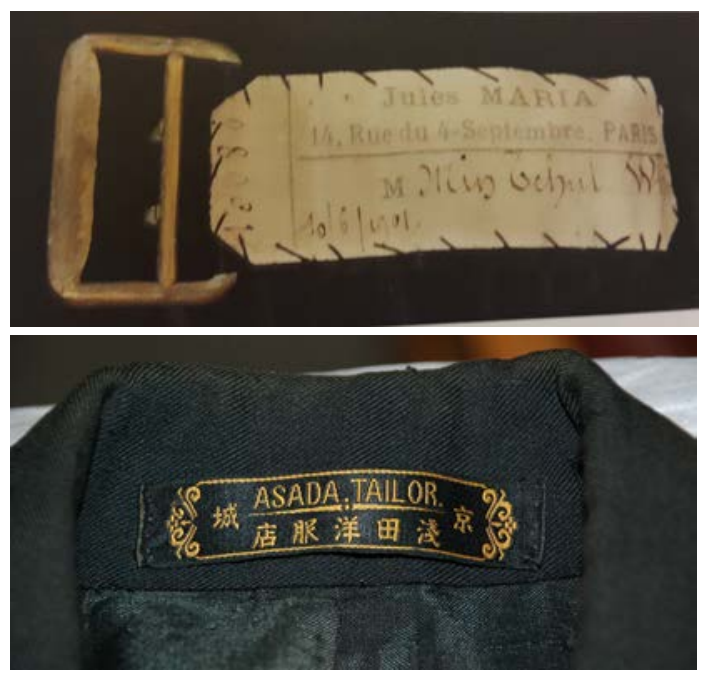

<Fig. 7> Brand label

From. Kyungwoon Museum. (2012). p.65 \& Photographed by the author. (January 10, 2012)
서양 의복의 도입이 빨랐던 일본인의 서울 양복점의 가능성이 더 높을 것으로 생각되어진다(Choi, 2015).

\section{Shape and character}

조끼의 형태는 앞길이가 뒤길이보다 길며, 뒤허리 에는 모두 좌우 옆선에 허리벨트가 달려있어 여밈의 정도를 조정할 수 있게 되어 있다. 조끼들은 모두 $\mathrm{V}$ 네크라인을 하고 있으나, 박기준의 조끼는 금색 선장 식이 네트라인에 둘러져 있고 박기종의 조끼 2점은 모두 테일러드 칼라 형태를 한 숄칼라가 달려 있었다.

앞여밈은 단추여밈으로 되어 있으며 대례복의 조끼 들은 금색 단추로 싱글여밈을 하고 있으며 소례복으 로 사용되었던 조끼들은 싸개단추의 검은색 단추로 되어 있다. 박기종의 조끼의 경우는 싱글브레스트와 더블브레스트 두 가지가 다 보였고, 기증유물에서 대 례복과 소례복이 구분되지 않고 포함되어 있었는데, 둘 다 싸개단추를 하고 있었으므로 단추의 재질로 구 분해 볼 때 2점 모두 소례복용 조끼로 추정되어졌다.

그리고 더블브레스트의 조끼는 옆선위치에 짧은 옆트임을 나타내었고 앞여밈 부분이 Davis(1994)의 Men's Garments의 1890년대 패턴처럼 따로 분리되 어 있지 않고 앞길이 연장되어 한 장으로 되어져 있 었다. Davis(1994)가 '19세기 웨이스트코트는 싱글브 레스트와 더블브레스트 스타일 모두 입혀졌으며, 싱 글브레스트 스타일이 더 대중적이었다'고 밝히고 있 는 것처럼 대한제국기 유물인 남자 조끼 연구 자료들 에서도〈Table 1)과 같이 싱글브레스트 스타일이 더 많이 나타났었다.

\section{1) Color / Material}

조끼는 앞길은 검은색 모직물으로 제작되어져 있 고, 뒷길은 검은색 견직물으로 되어 있으며, 좌우 앞 여밈부분에는 검은색 모직물로 안단(facing)을 대었 다. 안감은 아이보리색 평직 또는 능직 견직물로 구 성되어져 있고, 주머니 안감으로 아이보리 생견, 검은 색 견, 갈색 면직물이 사용되었다. 박기종의 조끼 2점 은 안칼라에 얇은 갈색 면직물이 심지처럼 힘받이로 부착되어 있었다.

당시에 사용된 모직물들은 Kum et al.(2002)의 연구 에서 서양복 수용 초기의 양복지는 주로 수입품에 의 존한 것으로 모직물은 1894년까지는 대부분 영국제 
$<$ Table 1> Materials of research (vests of the Korea Empire)

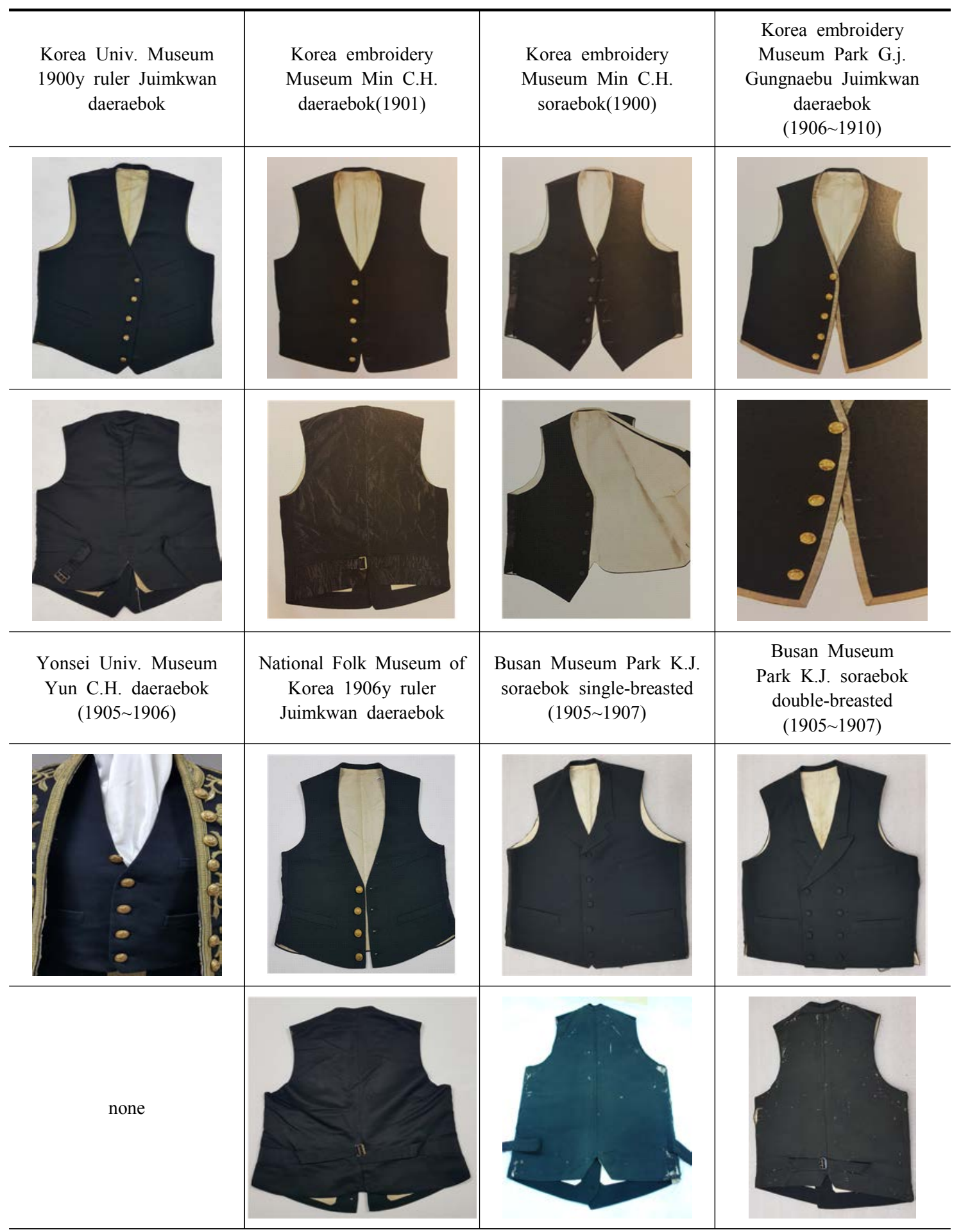

From. Kyungwoon Museum. (2012). pp. 64-65, 84, 104 \& Photographed by the author. (January 10, 2012 \& November 11, 2016 \& November 21, 2016) 
였으며, 1895 1904년까지는 일본제와 영국제의 비중이 각각 절반씩 차지하였으며, 1905 년 이후는 일본제품 이 영국제품을 압도하였다고 한 것처럼 대부분의 모 직물은 조끼 제작이 프랑스, 러시아, 일본, 경성 등에서 만들어지고, 착용 시기를 고려해 볼 때 유럽의 해당 제작국가의 자국제 또는 영국제, 일본제로 추측된다.

\section{2) Pattern}

연구자료 조끼들은 Davis(1994)의 Men's Garments 의 1850 1900년대 조끼 패턴 〈Fig. 9〉와 비교해 보면 1850 1900년대 싱글브레스트 스텝칼라베스트의 경 우, 뒷목둘레부분의 형태가 패턴에서 $1 \mathrm{~cm}$ 씩 올라오 고, 앞길에서 칼라부분만 따로 만들어 달고 있다.

그러나 칼라가 달려있던 박기종의 싱글브레스트와 더블브레스트 조끼는 솔칼라로 칼라와 라펠이 구분 되지 않고, 칼라가 앞길에서 뒷목중심까지 하나로 연 결되고, 칼라외곽선만 〈Fig. 10〉과 같이 너치드와 피 그드 같은 형태를 하고 있다. 이처럼 칼라와 라펠이 하나로 연결된 형태는 1850 1900년대의 스텝칼라와 같은 방법이었으나, 뒷목둘레까지 연결되는 것은 〈Fig. $8>$ 의 1830 1840년대 롤칼라와 같은 방법이었다.

그리고 나머지 V네크라인 싱글브레스트 조끼들의 뒷목둘레는 〈Fig. 9〉의 1850 1900년대의 패턴처럼 $1 \mathrm{~cm}$ 씩 올리지 않고, 안칼라는 앞길 안단에서 롤칼라 패턴처럼 뒷목둘레의 스탠드 분량만큼 패턴이 연결 되어 만들어지고, 뒷목둘레의 겉칼라는 〈Table 2〉의 유물 형태처럼 스탠드분을 따로 덧대어 만들었다. 대 한제국기의 조끼의 패턴은 $19 \mathrm{C}$ 다양한 패턴 방식이 절 충 및 조합되어 만들어진 형식이었음을 알 수 있었다.

$19 \mathrm{C}$ 패턴은 뒷길의 아랫단 모습이 평평하게 좌우
연결되어 있으나, 대한제국기의 조끼들은 대부분 너 치드 효과를 내듯이 사선으로 뒷중심이 경사져 있는 것이 차이 났다.

\section{3) Front bodice}

연구자료 조끼는 모두 앞길이가 뒷길이보다 길게 나타났으며, 앞길의 형태는 앞중심 아랫단부분의 형 태에 따라 〈Table 3〉과 같이 몇 가지 유형으로 나타 났다. 유형은 앞중심이 각지게 아랫단으로 넘어가며, 아랫단 부분이 부드러운 곡선 유형(3점), 앞중심이 짧 은 사선으로 경사지며, 아랫단이 경사진 유형(2점), 앞중심이 부드러운 곡선으로 아랫단이 평평한 유형(2 점), 앞중심이 경사가 크고 긴 사선으로 뾰족하고 오 목하게 휘는 곡선 유형(1점)로 분류되었다. 그리고 앞 길의 겉감에는 다트의 봉제선이 보이지 않았다.

\section{4) Back bodice}

뒷길은 사진자료 또는 실측과 촬영으로 확인 가능 한 7점의 유물(윤치호 제외)에서 모두 검은 검은색 실크로 제작되고, 뒷중심에 솔기선이 있으며, 뒤중심 부분의 밑단이 사선으로 되어져 삼각형 모양의 너치 드(notched)효과를 나타내고 있었다.

그리고 뒤허리 좌우 옆선에 끼워져 뒷길에 일정부 분 고정되어 있는 허리벨트가 뒷모습이 확인 가능한 6점의 유물에서 나타났었다. 이상의 결과로 뒷길 전 체가 확인되지 않은 3점의 유물 역시 비슷한 양상을 나타내고 있지 않을까 추측되었다. Davis(1994)의 Men's Garments의 삽화를 보면 1830 1840년대 조끼 허리벨트는 〈Fig. 8>과 같이 뒷길의 중심부분에만 있 으며, 1850 1900년대의 조끼허리벨트는 〈Fig. 9〉와 같
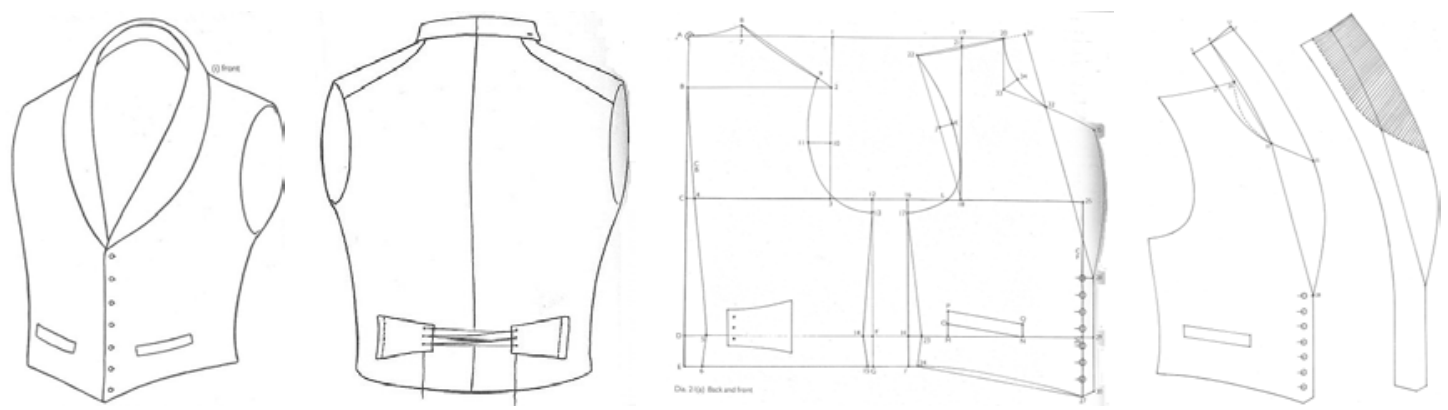

<Fig. 8> Single-breasted roll-collar waistcoat (1830 1840s) From. Davis. (1994). pp. 106-109. 

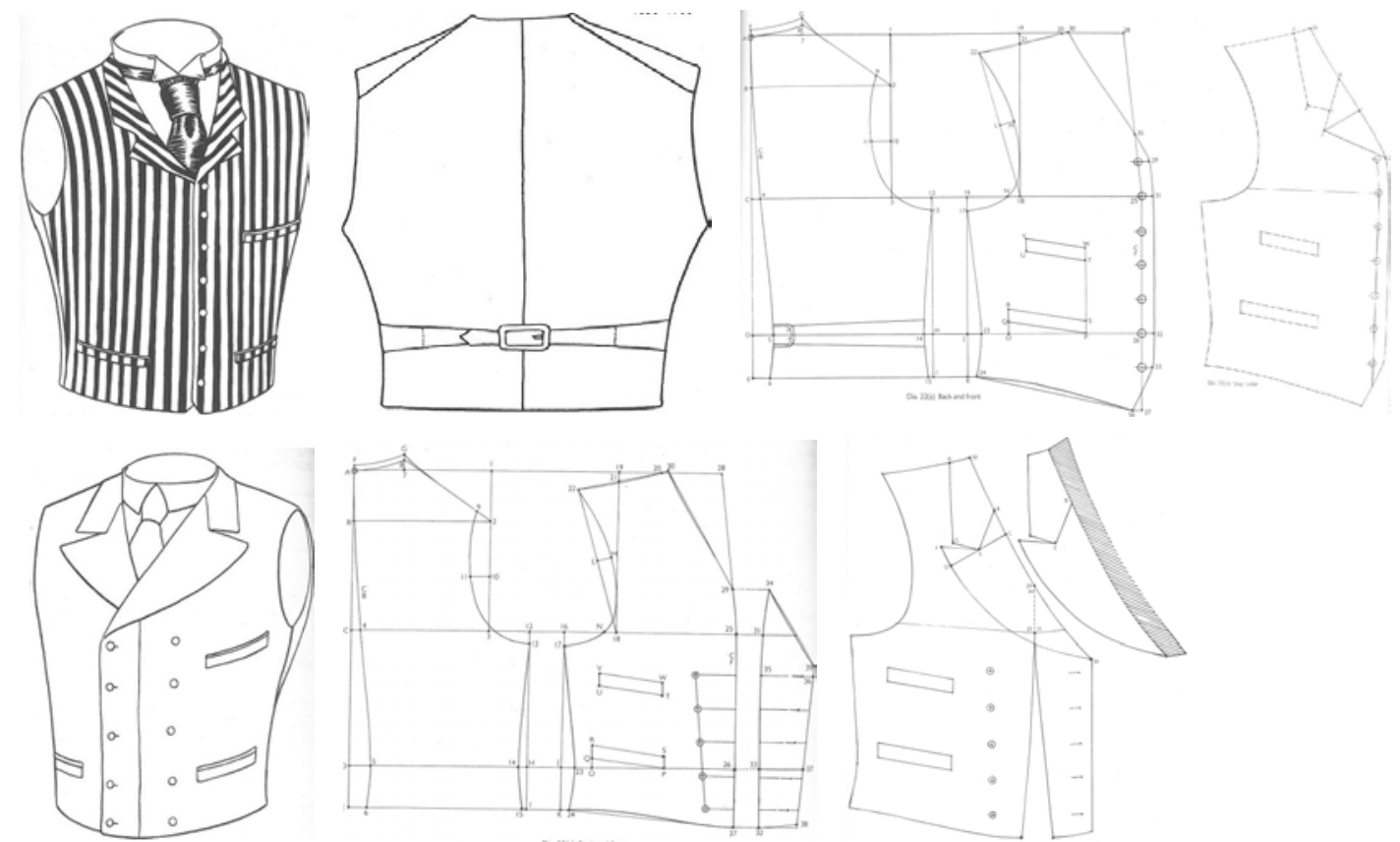

<Fig. 9> Single-breasted step-collar waistcoat \& double-breasted waistcoat (1850 1900s) From. Davis. (1994). pp. 112-114, 116-117.

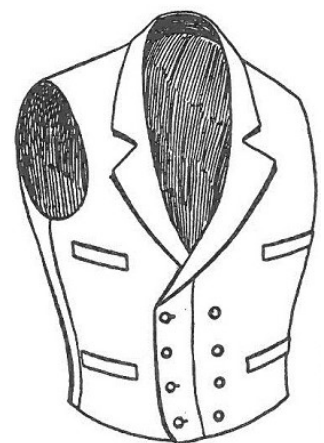

<Fig. 10> Fake notched collar From. Davis. (1994). p. 116.

이 좌우옆선에서부터 달려 있다. 대한제국기 유물조 끼 역시 1900년대에 해당하는 옆선에서 달려있는 조 끼 형태를 나타내고 있음을 볼 수 있었다.

\section{5) Pocket}

연구자료 모두 공통으로 왼쪽가슴부위에 1 개, 좌우 허리선에 각각 1 개씩의 웰트주머니(welt pocket)가 있 으며, 주머니들은 모두 앞 중심을 향해서 내려가는 경사방향으로 위치하고 있다. 허리주머니는 가슴주머
니보다 웰트의 높이도 높고, 너비도 넓은 형태를 하 고 있었다. 왼쪽 길의 위아래에 위치한 웰트주머니의 시작은 앞중심으로 부터 같은 위치에서 시작하여 위 아래 일직선을 나타내었다.

\section{6) Neckline / Collar}

연구자료 조끼는 모두 $\mathrm{V}$ 네크라인을 나타내고, 뒷 목둘레 부분 스탠드 칼라는 검은색 모직물로 따로 스 탠드분을 덧대어 제작되고, 안칼라는 앞길 안단이 뒤 목중심까지 연장되어 검은색 모직으로 제작되어 있다.

박기준의 대례복 조끼 네크라인부분은 금사편직의 브레이드 같은 것이 앞여밈부분에서 아랫단까지 상 침으로 장식되어져 있고, 민철훈의 소례복 조끼는 아 이보리색 파이핑이 네크라인 부분에 장식되어져 있 어, 안단으로 처리된 안칼라 모직부분이 뒷목둘레부 분에서 거의 가려져 있다.

박기종 조끼 2점은 모두 칼라가 달려 있다. 칼라는 숄칼라의 외곽선을 테일러드 재킷의 너치드칼라(notched collar)와 피크드칼라(picked collar)처럼 모양내어 만 들고, 너치드 부분과 피그드 부분의 일부분 을 앞길 에 손바느질로 고정시키고, 뒤목둘레의 칼라는 꺽임 
$<$ Table 2> Shape of research vests

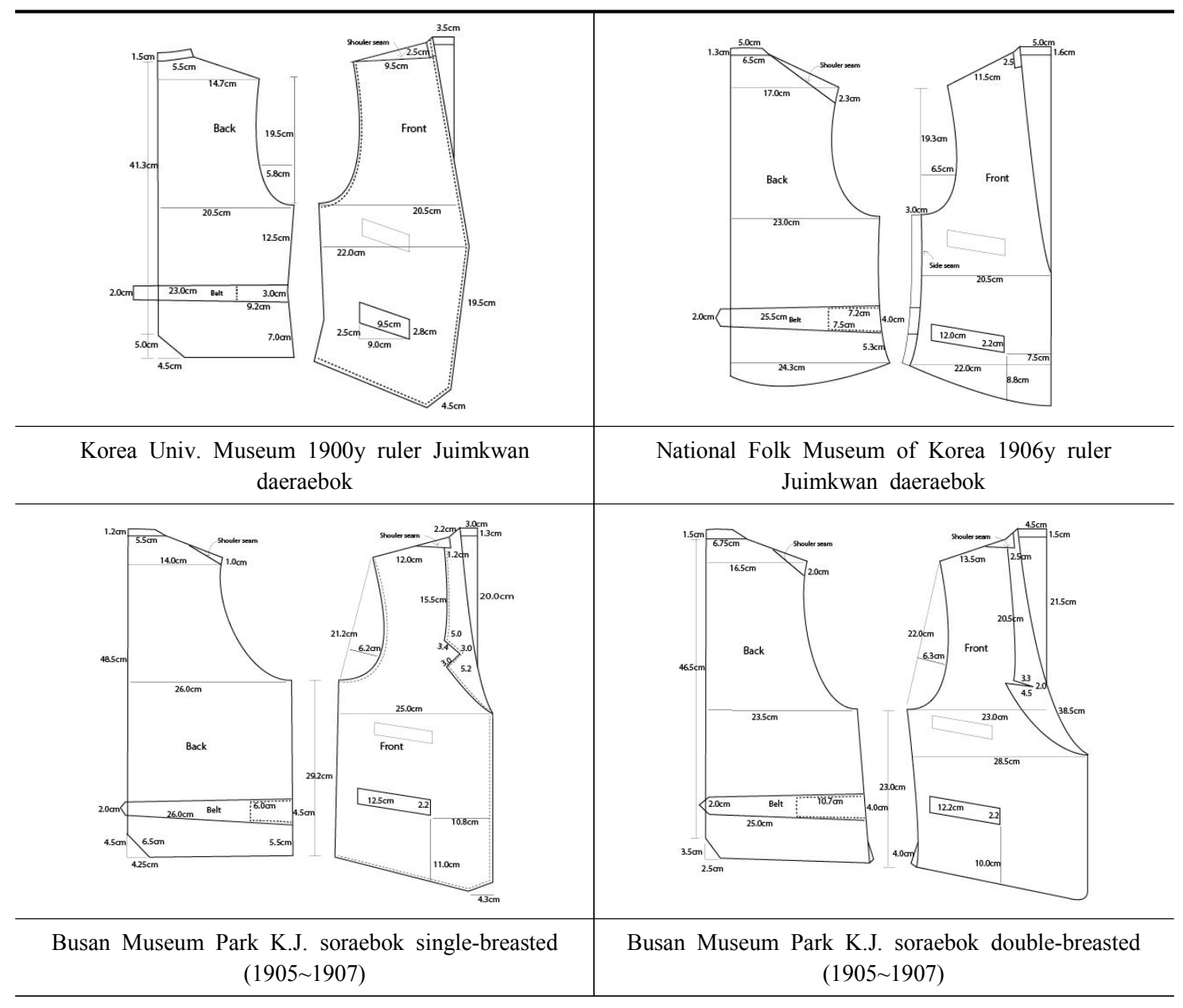

$<$ Table 3> Shape of front hem

\begin{tabular}{c|c|c|c}
\hline $\begin{array}{c}\text { Angular and } \\
\text { soft curve hem }\end{array}$ & Short sloping hem & $\begin{array}{c}\text { Curved and } \\
\text { flat hem }\end{array}$ & $\begin{array}{c}\text { Long sloping and point } \\
\text { curved hem }\end{array}$ \\
\hline & 2 items & 2 items & 1 item \\
\hline
\end{tabular}

From. Kyungwoon Museum. (2012). p. 64, 84 \& Photographed by the author. (November 11, 2016 \& November 21, 2016)

선에서 꺾어져 있으나, 뒷길의 검은색 실크가 뒤목둘 레 부분의 칼라위에 손바느질로 고정되어 $\mathrm{V}$ 네크라인 의 다른 조끼들처럼 스탠드칼라처럼 보였다. 또, 2점
모두 안칼라쪽 겉면에 칼라의 형태유지를 위한 심 역할 로 갈색 면직물의 칼라형태 심감이〈Fig. 11〉과 같이 박혀져 있었다. 이는 Davis(1994)가 말하는 '1850년대 

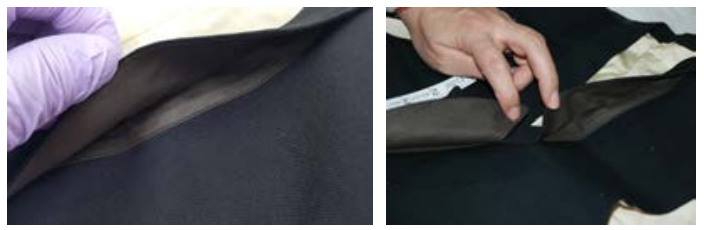

<Fig. 11> Under collar with attachment Photographed by the author.

(January 10, 2012 \& March 2, 2017)

이후로 대중적이었다는 칼라와 라펠이 하나로 결합 되고, 조끼와 별도로 만들어져 조끼 앞길의 네크라인 에 따로 앉혀 안쪽의 안감이랑 연결되며, 칼라가 뒤 목둘레까지 계속하여 둘러지지 않고 어깨솔기에서 바느질되어지는 형태였다'는 칼라 앞부분만 있는 스 탭칼라(step collar)와 외관은 비슷하나, 다른 형태의 칼라였다.

\section{7) Facing / Lapel}

안단은 〈Table 4〉와 같이 뒷목둘레 부분의 안칼라에 서부터 모두 겉감과 동일한 검은색 모직으로 되어져 있으며, 당시의 모직물이 대부분 수입산에 의존하던 시기였으므로 안단은 조끼를 만들고 남는 자투리 원 단들을 사용하여 안단을 구성한 듯 실측 가능하였던 4점 조끼 모두에서 조각을 이어서 만든 안단으로 되 어져 있었다. 박기종의 칼라가 달린 2점의 조끼도 겉 감과 같은 검은색 모직의 안단이 라펠로 사용되었다.

\section{8) Lining}

앞, 뒷길의 안감은 대부분 아이보리색의 견직물로 평직의 명주, 능직의 견, 수자직의 공단 등을 사용하 였다. 주머니의 안감으로는 아이보리색 견직물이나 검은색 견직물, 갈색의 면직물이 사용되었다.

\section{9) Fastening / Button}

8점의 유물 중 싱글브레스트 여밈은 7점으로 그 중 조끼 6 점은 5 개의 금색단추 또는 검은색 싸개단추로 되어 있고, 1 점은 4 개의 금색단추로 되어 있었다. 모 두 오른쪽 앞길에 단추가 달리고, 왼쪽에 단추구멍이 있어 왼쪽이 위로 올라오게 여며졌다. 그러나 윤치호 의 조끼는 5 개 단추 중 1 개는 장식용으로 네크라인 시작 부분에 달려 있고, 4 개로 옷을 여미게 되어있었 다. 더블브레스트 여밈은 박기종 조끼 1점으로 검은 색 싸개단추가 4 개씩 2줄로 달려 있으며, 오른쪽은 여밈용 1 줄과 단추구멍 한 줄, 왼쪽은 단추구멍 한 줄 과 장식용 1 줄로 되어 있다.

대례복의 금색단추는 〈Table 5〉와 같이 민철훈의 조끼단추에는 6 개의 꽃잎문양, 박기준의 조끼단추에 는 조선왕실의 상징인 이화문, 윤치호 조끼와 민속박 물관 1906년 제식의 조끼단추에는 무궁화 문양이 장 식되어져있으며 고려대학교박물관 1900년 제식의 조 끼 단추에는 문양의 흔적이 있는듯하나 뚜렷하지 않 았다.

$<$ Table $4>$ Lining \& shape of facing (2 piece)

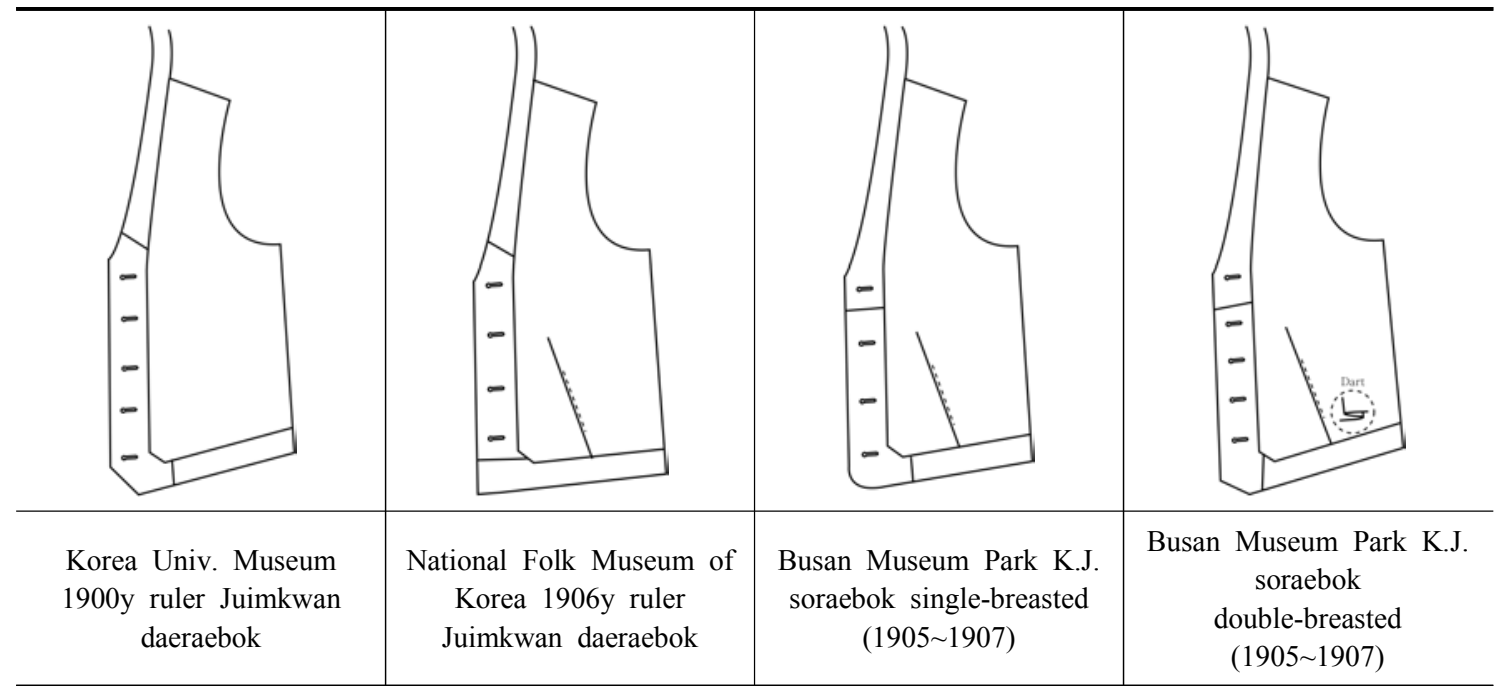


$<$ Table 5> Patterns of Button

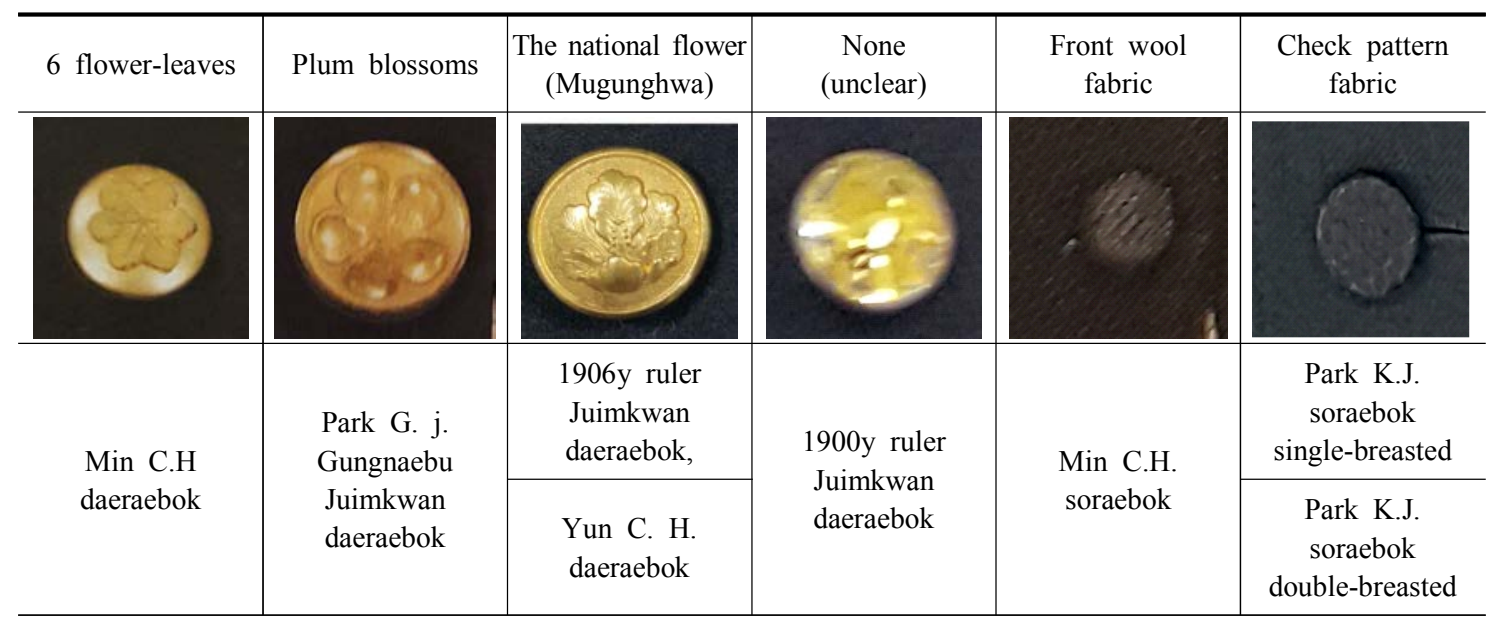

From. Kyungwoon Museum. (2012). p. 64, 84, $104 \&$ Photographed by the author. (January 10, 2012 \& November 11, 2016 \& November 21, 2016 \& March 24, 2017)

그리고 소례복의 싸개단추의 경우, 민철훈의 조끼 단추는 겉감과 같은 모직물로 감싸져 있고, 박기종의 조끼단추는 격자무늬 조직의 검은색 천으로 감싸져 있었다. 장식문양에서 당시 역사적으로 어려운 시기 였음에도 조선왕실의 주체성을 지키면서 다양한 서 구문화를 수용하였음을 엿볼 수 있었다.

\section{0) Connecting method of lining and upper}

안 - 겉감은 뒷길아랫단, 진동둘레 부위는 바느질 로 연결되어 있고, 앞길 안단과 아랫단, 뒤목둘레 부 분은 손바느질 감치기로 연결되어 있었다. 1900년 제 식 주임관 대례복 조끼와 박기종의 조끼 2점은 가장 지리 부분에 상침으로 고정되어 있었다.

\section{Size}

연구자료 조끼들의 사이즈는 〈Table 6)과 같다. 8 개의 조끼 중 실측이 가능하였던 4 개의 조끼를 중심 으로 치수를 살펴보면 뒤길이 $47.5 \sim 52.5 \mathrm{~cm}$, 뒤중심길 이 $41.3 \sim 47.3 \mathrm{~cm}$, 뒤품 $41 \sim 52 \mathrm{~cm}$, 앞품 $41 \sim 47 \mathrm{~cm}$ 이며, 진동깊이 $19.3 \sim 20.7 \mathrm{~cm}, 1 / 2$ 뒷목둘레 $5.5 \sim 7.0 \mathrm{~cm}$, 뒷칼 라높이 $1.2 \sim 1.3 \mathrm{~cm}$, 옆길이 $22.3 \sim 29.2 \mathrm{~cm}$, 주머니 웰트 크기(상2.0 2.5×8 10/하 2.2 2.9×9 12.5)cm, 옆트임 이 있는 경우 트임 길이는 $4 \mathrm{~cm}$ 를 나타내었다. 안감에 앞허리다트가 있는 경우 다트 길이는 $13.0 ~ 22.7 \mathrm{~cm}$ 를 나타내었다.

\section{Tailoring}

\section{1) Front bodice}

앞길은 모직물로 만들어져 있으며, 겉감에는 다트 가 없고, 왼쪽가슴과 좌우허리에 웰트주머니가 달려 있다. 대부분 V네크라인으로 안단과 함께 앞여밈까 지 박음질한 후 뒤집어 다림질한 모습을 하고 있다. 고려대학교 박물관의 1900년 제식 주임관 대례복 조끼와 박기종의 조끼 2점은 안단이 밀려나오지 않도 록 네크라인과 앞여밈부분에 가장자리를 따라 겉에 서 누름상침으로 박음질되어져 있고, 박기준의 궁내 부 주임관 대례복 조끼는 금사편직 브레이드가 가장 자리를 따라 상침되어져있다. 민철훈의 소례복 조끼 는 아이보리색 견으로 파이핑 처리가 네크라인 부분 에 되어져 있어 안칼라 부분이 아이보리 실크로 감싸 져 있었다. 박기종 조끼 2점은 솔칼라가 달려 있으며, 칼라외곽선이 재킷의 너치드 칼라와 피그드 칼라 형 태를 나타내며, 마치 테일러드 칼라가 달려있는 것처 럼 보여지고 안단이 라펠역할을 하고 있었다.

\section{2) Shoulder seam}

어깨솔기선은 〈Table 7〉과 같이 고려대학교 박물관 의 1900 년 제식 주임관 대례복의 경우, 뒷길이 앞길 쪽으로 넘어와 뒷길의 실크부분이 양 어깨에 나타난다. 민속박물관의 1906년 제식 주임관 대례복 조끼는 어 


\begin{tabular}{|c|c|c|c|c|c|c|c|c|}
\hline & \multicolumn{5}{|c|}{ Daeraebok } & \multicolumn{3}{|c|}{ Soraebok } \\
\hline & $\begin{array}{l}1900 y \\
\text { ruler }\end{array}$ & Yun C.H. & $\begin{array}{c}1906 y \\
\text { ruler }\end{array}$ & Park G.j. & Min C.H. & Min C.H. & $\begin{array}{c}\text { Park K.J. } \\
\text { single } \\
\text { breasted }\end{array}$ & $\begin{array}{c}\text { Park K.J. } \\
\text { double } \\
\text { breasted }\end{array}$ \\
\hline Front length & - & - & - & 54.5 & - & - & 59.5 & 55.5 \\
\hline C. back length & 41.3 & - & & \multirow{3}{*}{48.0} & \multirow{3}{*}{52.0} & \multirow{3}{*}{49.5} & 47.3 & 45.8 \\
\hline Back collar height & 1.2 & - & 1.3 & & & & 1.2 & 1.2 \\
\hline Back oblique height & 5.0 & - & & & & & 4.5 & 3.5 \\
\hline Side length & 22.5 & - & 24.0 & - & - & - & 29.2 & 23.0 \\
\hline Side slit & - & - & - & - & - & - & - & 4.0 \\
\hline $1 / 2$ front neck width & 3.5 & - & 5.0 & - & - & - & 3.0 & 4.5 \\
\hline $1 / 2$ back neck width & 5.5 & - & 7.0 & & & & 5.5 & 6.75 \\
\hline $1 / 2$ shoulder width & 14.7 & - & 17.0 & - & - & - & 14.0 & 16.5 \\
\hline Front width & 44.0 & - & 40.6 & - & 41.5 & 46.5 & 50.0 & 47.0 \\
\hline $1 / 2$ back width & 20.5 & - & $26(23)$ & - & - & - & 26.0 & 23.5 \\
\hline Belt width $\mathrm{L} / \mathrm{R}$ & $\begin{array}{l}2.8(2.0) \\
3.0(2.0)\end{array}$ & - & $\begin{array}{l}4.0(2.0) \\
4.0(2.0)\end{array}$ & - & - & - & $\begin{array}{l}4.5(2.0) \\
4.5(2.0)\end{array}$ & $\begin{array}{l}4.0(2.0) \\
4.0(2.0)\end{array}$ \\
\hline Belt length $\mathrm{L} / \mathrm{R}$ & $\begin{array}{l}19.0 \\
23.0\end{array}$ & - & $\begin{array}{l}24.5 \\
25.5\end{array}$ & - & - & - & $\begin{array}{l}26.0 \\
25.0\end{array}$ & $\begin{array}{l}22.0 \\
24.3\end{array}$ \\
\hline Armhole depth & 19.5 & - & 19.3 & - & - & - & 19.5 & 20.7 \\
\hline Armhole width & $8.0(6.5)$ & - & 6.5 & - & - & - & 9.0 & 9.0 \\
\hline Brest pocket & $2.5 * 8$ & $2.0^{*}$ & $2.0 * 9.8$ & - & - & - & $2.0 * 10.0$ & $2.0^{*}$ \\
\hline Waist pocket & $2.8 * 9$ & $2.0^{*}$ & $2.2 * 12.0$ & - & - & - & $2.2 * 12.5$ & $2.2 *$ \\
\hline Button size & $13.0 \mathrm{~mm}$ & $19.9 \mathrm{~mm}$ & $19.0 \mathrm{~mm}$ & - & - & - & $14.0 \mathrm{~mm}$ & $14.0 \mathrm{~mm}$ \\
\hline Buttonhole & $24.0 \mathrm{~mm}$ & - & $22.0 \mathrm{~mm}$ & - & - & - & $20.0 \mathrm{~mm}$ & $20.0 \mathrm{~mm}$ \\
\hline Facing width & $4.2 / 4.0$ & - & $4.5 / 4.8$ & - & - & - & $5.3 / 5.0$ & $5.5 / 5.3$ \\
\hline Hem width $\mathrm{F} / \mathrm{B}$ & $\begin{array}{c}3.3 \sim 1.3 \\
/ 0.4\end{array}$ & - & $\begin{array}{c}1.7 \\
/ 0.3\end{array}$ & - & - & - & $\begin{array}{c}3.4 \sim 5.5 \\
/ 0\end{array}$ & $\begin{array}{c}4.5 \sim 4.0 \\
/ 0\end{array}$ \\
\hline Dart length of lining & none & - & 13.0 & - & - & - & 17.0 & 22.7 \\
\hline
\end{tabular}

깨솔기가 뒤쪽으로 넘어가 앞길의 모직부분이 뒷길 양어깨에서 나타난다. 박기준의 궁내부 주임관 대례 복은 앞모습사진 뿐이며, 앞길 사진에서 전혀 뒷길의 실크 감이 보이지 않으므로 어깨솔기가 뒤로 넘어간 형태가 아닐까 생각되어진다. 민철훈 대례복과 소례 복의 조끼 2점은 모두 뒷길이 앞으로 넘어와 검은 실 크가 앞쪽에서 보인다. 박기종 조끼 2점은 모두 어깨
솔기선의 경사가 옆목점쪽은 뒷길의 실크가 앞으로 넘어와 있고, 어깨끝쪽은 앞길의 모직부분이 뒷길쪽 으로 조금 넘어가져 있다. 시접의 방향은 옷감의 두 께감이 얇은 뒷길을 향하고 있다.

\section{3) Side seam}

옆솔기선은 모직물과 견직물의 재질 차이로 두께 
$<$ Table 7> Position of shoulder seam

\begin{tabular}{|c|c|c|c|}
\hline & Front bound & Back bound & Mix bound \\
\hline \multirow{2}{*}{$\begin{array}{l}\text { Shape of } \\
\text { shoulder } \\
\text { seam }\end{array}$} & wool & $\begin{array}{c}\text { wool } \\
\text { F }\end{array}$ & $\begin{array}{c}\text { wool } \\
\text { F }\end{array}$ \\
\hline & silk & & silk \\
\hline Items & $\begin{array}{l}\text {-1900 rules Juimkwan } \\
\text { Daeraebok vest } \\
\text {-Min C.H. Daeraebok vest } \\
\text {-Min C.H. Soraebok vest }\end{array}$ & $\begin{array}{l}\text {-Park G.J. Gungnaebu } \\
\text { Juimkwan Daeraebok vest } \\
\text {-1906 rules Juimkwan } \\
\text { Daeraebok vest }\end{array}$ & $\begin{array}{l}\text {-Park K.J. single breasted vest } \\
\text {-Park K.J. double breasted vest }\end{array}$ \\
\hline
\end{tabular}

감이 달라 시접은 뒷길의 실크쪽으로 홑솔로 넘어가 게 처리되어 있다. 조끼의 평면사진 촬영에서 옆선 솔기선의 위치가 앞으로 넘어온 것, 옆선 위치에 있 는 것, 뒤로 넘어간 것 등의 3 가지 형태로 나타났다. 앞뒤너비를 계측한 결과, 유독 앞뒤차가 큰 민속박물 관의 1906년 제식 주임관 대례복은 착용자의 체형으 로 인한 치수차이가 큰 것으로 추측되었다. 모든 조 끼의 옆선 허리선 위치에는 뒷길에서 여며지는 허리 벨트가 삽입되어 바느질되어져 있었다.

\section{4) Side slit}

옆트임은 〈Fig. 12〉와 같이 박기종의 더블브레스트 조끼에서만 나타났으며, 옆트임의 길이는 $4 \mathrm{~cm}$ 로 옆 트임 끝부분에는 손바느질로 바택 처리와 같은 끝막 음처리가 되어져 있다.

\section{5) Center back seam}

뒷중심솔기선은 확인 가능한 7점(윤치호 조끼 제외)
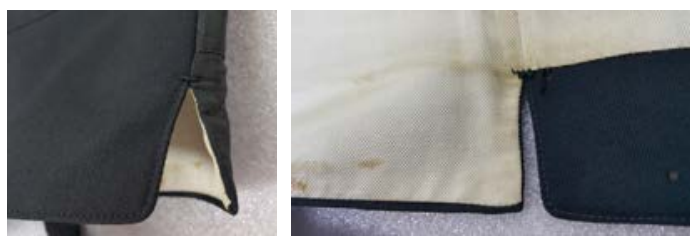

<Fig. 12> Shape of side slit (surface \& inner) Photographed by the author.

(January 10, 2012 \& March 24, 2017)
모두 있으며, 뒤중심 아랫단 부분이 너치 모양처럼 사선 으로 꺾어지는 아랫단 형태를 하고 있으며, 시접은 입어 서 왼쪽으로 홑솔처리되어 있었다. 고려대학교 박물관 의 1900 년 제식 주임관 대례복 〈Fig. 14〉의 뒷중심은 오늘날 재킷의 안감에서 활동성을 위해 속주름을 처 리하는 것처럼 $2 \mathrm{~cm}$ 깊이의 외주름 처리가 입어서 왼쪽 으로 들어가 있어 착용 시 여유분을 제공하고 있었다.

\section{6) Facing}

안단은 하나의 조각으로 되어 있지 않고 자투리 옷 감을 사용한 듯 〈Table 4〉와 같이 2조각으로 연결하여 구성되어 있다. 첫 번째 조각은 뒤칼라 중심에서 출 발하여 앞네크라인이 끝나기 직전까지 한 장으로 연 결되어 있고, 두 번째 조각은 앞네크라인 끝나는 부 분부터 앞아래단까지 한 조각으로 연결되어 앞길의 재물단과 아랫단에서 연결되어져 있다.

민속박물관의 1906년 제식 주임관 대례복 조끼는 두 번째 조각이 앞길 아랫단 시작하는 부위까지만 연결되 고 앞길 전체 아랫단은 제물단으로 되어 있었다. 박기종 의 유물 조끼 2 점은 칼라가 달려있어 안단이 라펠역 할을 하고 있으므로 첫 번째 조각이 앞여밈부분까지 내려와 두 번째 안단 조각과 연결되어 있었다. 안단들 은 모두 모직으로 되어있으므로 조각들의 연결 부위 시 접은 모직의 두께를 고려해 가름솔처리 되어 있었다.

\section{7) Waist belt}

허리벨트는 좌우옆선에 한 개씩 삽입되어 박음질 
되어 있다. 민속박물관 1906년 제식 주임관 조끼와 박기종 조끼 2점은 뒷길 겉감에 허리벨트의 상하 가 장자리가 일정 부분 수평으로 눌림상침으로 고정되고 상침이 끝나는 부분은 수직으로 겉감에는 박음질, 안 감에는 〈Fig. 13〉과 같이 새발뜨기 같은 X모양의 손바 느질 되어져 있다. 박기종 싱글 조끼 안감에는 새발뜨 기 바느질 자국만 남아 있고, 더블 조끼에는 홈질로 고정되어져있다. 고려대학교 1900년 제식 주임관 대 례복 조끼는 일정길이 떨어진 위치에 겉감에는 홈질, 안감에는 $\mathrm{X}$ 모양의 손바느질로 눌림상침 되어져있다. 일정부분 고정한 후 나머지 허리벨트 부분은 뒷길과 분리되어 허리를 조일 수 있도록 만들어져 있다.

왼쪽 허리끈 끝은 두 개의 고리가 있는 금속제 버 클이 달려있고, 박기종의 버클에는 'fine clothing'이 라는 글씨가 새겨져 있었다. 오른쪽 허리끈은 길이를 조정할 수 있도록 천으로 되어져 있는데, 끈의 끝부 분은 사각형 또는 삼각형 형태로 접어서 박음질되어 있다. 허리벨트는 옆선에서 조금 넓게 시작하여 뒷중 심쪽으로 갈수록 점점 좁아지고 있으며, 〈Fig. 14〉와 같이 끈의 안쪽 중앙 위치에 끈의 박음 솔기가 위치 하고 있었다.

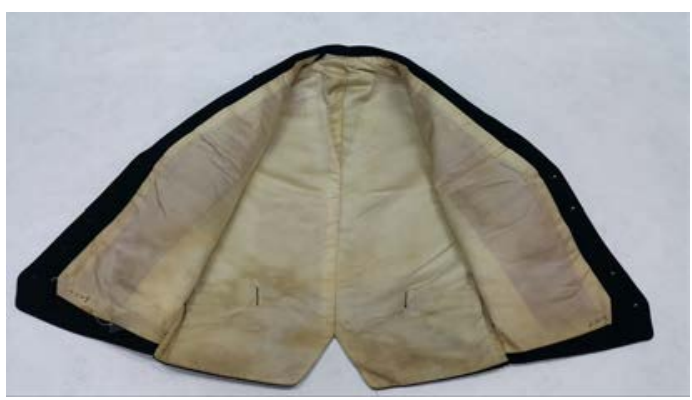

<Fig. 13> Shape of Inner(1900 ruler vest) Photographed by the author. (November 11, 2016)

\section{8) Pocket}

주머니는 왼쪽 가슴의 작은 크기의 웰트 주머니와 좌우허리에 큰 웰트 주머니가 각각 한 개씩 달려있으며, 웰트는 모두 앞 중심쪽이 낮게 경사져 달려 있었다. 〈Table 8)과 같이 고려대 1900년 제식 주임관 대례복 의 주머니입구는 가장자리부위에 장식상침과 웰트 좌우에 L자 모양으로 눌림상침이 있으며, 주머니감은 아이보리색 생견으로 웰트 가장자리 $0,3 \mathrm{~cm}$ 정도 아래 위치에 달려 있고, 주머니감이 밖으로 밀려나오지 않 도록 $0.5 \mathrm{~cm}$ 아래에 숨뜨기가 되어져 있었다. 윤치호 대례복 조끼의 주머니에는 가장자리 상침이 나타나 지 않았다. 민속박물관 1906년 제식 주임관 대례복 조끼에서는 웰트 가장자리 상침이 없고, 주머니감은 검은색 견으로 웰트 가장자리에서 $1 \mathrm{~cm}$ 정도 내려온 곳에 달려 있었다. 박기종 조끼 2점의 주머니입구 가 장자리는 장식상침이 있으며, 웰트 좌우는 눌림상침 으로 고정하고, 모서리 부위는 사선으로 눌림상침이 되어져 있으며, 주머니감은 갈색 면으로 웰트 가장자 리에서 $0.9 \sim 1 \mathrm{~cm}$ 정도 내려온 곳에 달려있었다.

\section{9) Collar}

칼라는 모두 뒤목둘레 부분에만 하이넥(high neck) 처럼 스탠드 부분이 따로 덧대어져 뒤칼라 형태를 나

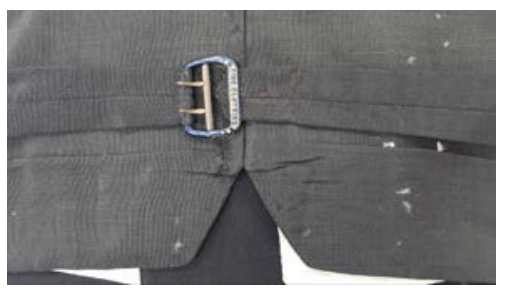

<Fig. 14> Back waist blet

Photographed by the author. (January 10, 2012)

$<$ Table 8> Stitch shape of welt edge

\begin{tabular}{|c|c|c|c|}
\hline $\begin{array}{l}\text { Edge stitch \& } \\
\text { 'L'shape stitch }\end{array}$ & $\begin{array}{l}\text { Edge stitch less \& } \\
2 \text { point fixed }\end{array}$ & $\begin{array}{l}\text { Edge stitch less \& } \\
4 \text { point fixed }\end{array}$ & $\begin{array}{l}\text { Edge stitch \& } \\
\text { diagonal stitch }\end{array}$ \\
\hline & & $\sqrt{1}$ & \\
\hline $\begin{array}{c}1900 \text { rules Juimkwan } \\
\text { Daeraebok vest }\end{array}$ & $\begin{array}{c}\text { Yun C.H. } \\
\text { Daeraebok vest }\end{array}$ & $\begin{array}{c}1906 \text { rules Juimkwan } \\
\text { Daeraebok vest }\end{array}$ & $\begin{array}{c}\text { Park K.J. single \& double } \\
\text { breasted vest }\end{array}$ \\
\hline
\end{tabular}


타내며, 안칼라 부분은 앞길 안단에서 연장되어 박음 질 되어졌다.

그러나 박기종의 조끼 2점은 솔칼라가 달려 있고, 라펠이 겉으로 넘어와 만든 칼라 외곽선 모양이 〈Fig. $15>$ 와 같이 너치드 칼라와 피크드 칼라의 형태로 만 들어져 있었다. 뒤목둘레 부분의 칼라는 롤칼라 형태 를 완성하고 있으나, 뒷길의 검은색 실크가 칼라 위 로 올라와 감침질로 칼라를 고정하고 있어 마치 뒤칼 라는 나머지 조끼들과 같이 스탠드분만 있는 것처럼 보여졌다. 박기종 조끼 2점은 모두 완성된 안칼라의 겉쪽에〈Fig. 11〉과 같이 갈색 면으로 심감처럼 칼라 모양으로 만들어 칼라 꺾임선 너머까지 덧대어져 힘 받는 역할을 하고 있으며, 안칼라의 칼라와 라펠이 분리되었는지 한 장으로 되었는지 확인하기가 어려 웠으나, 바느질자국을 찾기 어려워 겉칼라처럼 앞길 에서 뒤칼라까지 연결하여 한 장으로 만들어진 것처 럼 추측된다. 칼라의 외곽선 중 너치드와 피그드 형 태의 가장자리의 꺾임부분은 손바느질로 앞길 겉감 에 칼라모양이 움직이지 않도록 고정되어 있었다.

\section{0) Button and button hole}

단추 구멍은 여밈용 단추 구멍이〈Fig. 16〉과 같이 앞길 왼쪽에 4 5개씩 수평으로 뚫어져 있으며, 단추 구멍은 앞여밈 가장자리에서 $1.0 \sim 2 \mathrm{~cm}$ 떨어진 곳, 단 추는 앞여밈 가장자리에서 $1.3 \sim 2.0 \mathrm{~cm}$ 떨어진 곳에 위 치하도록 구성되어져 있다.

박기종 더블브레스트 조끼는 좌우 양쪽 모두 한 줄 의 단추구멍과 한 줄의 단추가 달려 있으며, 단추구 멍 끝부분에서 단추까지의 간격은 $5.2 \sim 6.3 \mathrm{~cm}$ 로 윗부 분이 간격이 멀고, 허리로 갈수록 간격이 좁아지고 있으며, 착용자의 체형이 허리쪽으로 갈수록 굵어지 는 체형임을 추측할 수 있었다.

여밈용 단추구멍은 오늘날 재킷처럼 시작이 둥글 면서 일자형태인 재킷단추구멍이 수평으로 뚫어져
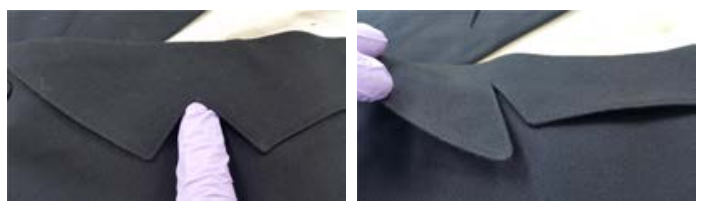

<Fig. 15> The shape of collar (notched/ picked) Photographed by the author. (March 24, 2017)
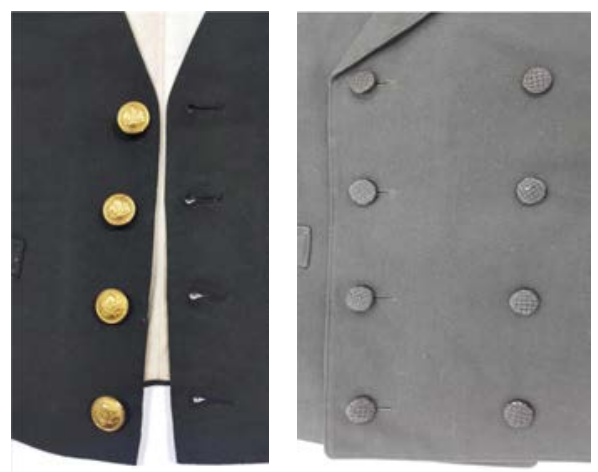

<Fig. 16> Button \& button hole Photographed by the author.

(November 24, 2017 \& January 10, 2012)

있었다.

\section{1) Lining}

안감은 모두 아이보리색 견직물로 되어 있으며, 실 측 가능하였던 조끼 4점 중 민속박물관 1906년 제식 주임관 대례복 조끼와 박기종 조끼 2점은 모두 안감 앞길에 허리다트가 좌우에 각각 하나씩 있으며, 다트 시접은 〈Table 4〉와 같이 옆선쪽으로 보내어져 있었 다. 허리다트는 지금의 다트 바느질같이 다트 전체를 박음질하지 않고, 다트길이 중 일부분을 손바느질로 고정하여 나머지 부분들은 외주름처럼 한쪽으로 넘 어가 있는 형태를 나타내었다.

그러나 고려대박물관 1900년 제식 주임관 대례복 조끼는 앞길 허리다트가 없고 뒷길 중심솔기에〈Fig. $13>$ 과 같이 속주름의 여유분이 들어 있었다.

\section{2) Connecting method of lining and upper}

겉감과 안감의 연결방법은 뒷길은 안 - 겉감이 모 두 견직물로 아랫단과 진동둘레 부분이 박음질로 연 결되어져 있고, 뒷길 아랫단은 거의 없으며, 앞길의 진동둘레는 박음질 되어 있고 안감과 안단, 안감과 아랫단의 연결부분은 손바느질로 감치기 또는 공그 르기로 바느질되어 있었다.

\section{Conclusion}

개항기는 국내외 정세에 더욱 민감했던 시기였기 때문에, 주변정세 변화에 따라 짧은 시간 안에 복식 
변화의 폭도 컸던 때라 할 수 있으며 그 중에서도 대 한제국 시기에는 관복에 있어서 양복도입이 이루어 지던 시기로 당시 생존하였던 인물들의 기증유물 중 대례복이나 소례복 일습에 포함되었던 8점 조끼의 특 성을 실증적 고찰한 결과는 다음과 같다.

연구자료 조끼 8점은 착용자 미상의 1900년 제식 주임관 대례복, 민철훈의 1900년대 모닝코트 소례복과 1901년 대례복, 윤치호의 1905 1906년 제식 대례복, 착용자 미상의 1906년 제식 주임관 대례복, 박기종의 1905 1907년 제식 칙임관 대례복과 프록코트 소례복 의 조끼들로 본 연구 조사 결과 대례복 일습의 조끼 들은 모두 금색 단추가 달려 있었고, 금색단추는 6 꽃 잎, 이화문, 무궁화문 등의 문양이 나타나고, 소례복 일습의 조끼들은 검은색 싸개단추로 구성되어 있음 을 알 수 있었다. 박기종의 조끼 2점은 대 - 소례복과 함께 구분 없이 기증되었으나, 이번 연구에서 2점 모 두 소례복의 조끼임을 알 수 있었다.

대한제국기의 연구자료 대례복과 소례복의 조끼들 은 1850 1900년대에 유행하였던 서양의 싱글브레스 트와 더블브레스트가 모두 나타나며, 당시 서양에서 싱글브레스트가 더 많이 착용되었다는 것처럼 대한제 국기에도 싱글브레스트 조끼가 더 많이 나타났다.

대부분 $\mathrm{V}$ 네크라인이며, 숄칼라가 달린 조끼는 칼 라외곽선이 너치드와 피크드 칼라와 같이 모양내어 져 테일러드 칼라처럼 보여지고, 이는 $19 \mathrm{C}$ 의 앞길에 만 칼라가 달리는 스텝칼라와 다른 형식으로 스탭칼 라와 롤칼라가 혼합되어진 형태를 나타내었다.

본 연구에서 고찰된 조끼들 중 고려대 1900년 주임 관 대례복은 러시아 L. Mihelson/St. Petersburg, 박기 준 대례복은 프록코트형 대례의로 소장자 면담에 의 해 일본, 윤치호 대례복은 러시아, 민철훈 대례복은 프랑스로 'Jules Maria/1901.6.10.Paris'라는 레벨이, 박 기종 소례복은 프록코트형으로 ASADA TAILOR/경 성 레벨이 부착되어 러시아, 프랑스, 일본 또는 우리 나라 등으로 대한제국기 당시 착용자의 직책에 따라 다양한 국가에서 주문제작되고, 이 무렵 서양복의 도 입으로 우리나라에까지 양복제작 업체가 생겼음을 알 수 있었다.

조끼의 소재로는 짙은 검은색 모직물과 검은색 견 직물 겉감과 아이보리색 견직물 안감을 사용하고, 안 칼라의 힘받이 역할로 갈색 면직물을 사용하였다. 주
머니감은 검은색과 아이보리색 견직물이나 갈색 면 직물을 사용하였다.

Men's Garments의 1850 1900년 조끼의 패턴과 비 교해 볼 때 차이점은 $19 \mathrm{C}$ 의 스텝 칼라와 같이 뒤목둘 레 부위의 칼라스탠드분이 패턴에서 뒤목높이를 $1 \mathrm{~cm}$ 정도 올리는 것으로 하지 않고, 뒷칼라 스탠드분 겉칼 라를 따로 덧대고, 안칼라는 안단에서 연장되어 만들 어지고, 더블브레스트의 앞여밈부분은 분리되어 구성 되지 않고 앞길이 연장되어 한 장으로 되어지며, 뒷 중심 아랫단이 평편하지 않고 삼각형으로 경사졌다 는 것이다.

테일러링의 특징으로 앞뒷길의 소재가 다르며, 어 깨솔기선의 위치가 뒤길이 앞으로 오는 형, 앞길이 뒤 로 가는 형, 옆목점부위는 뒷길이 앞으로/어깨끝점부 위는 앞길이 뒤로 가는 혼합형으로 나타났다. 겉감에 는 없는 앞 허리다트가 안감에만 있으며, 다트를 주 름처럼 일부분 눌림상침으로 처리하였다. 1점의 조끼 는 안감 등솔기 부분에 외주름의 여유분이 만들어져 있었다. 그리고 당시 수입 모직물로 의복이 제작되어 옷감을 절약한 구성법으로 앞여밈의 좌우안단이 한 장으로 되어있지 않고, 2장으로 상하 분리하여 재단 하고 구성한 방법 등이 나타났다.

본 연구에서 고찰된 결과는 대한제국기 당시의 착 용되었던 유물 중 조끼 8점에 한정하여 고찰하였기 때 문에 서구식 대례복, 소례복, 통상복 일습 중의 조끼 를 총체적으로 보는 것에는 다소 미흡한 점도 있지 만, 대한제국기 당시 착용되었던 조끼의 형태, 특성 및 구성법, 일부 도식화의 제시 등으로 차후 조끼의 복원 또는 재현을 하고자 할 때 중요한 기초자료가 될 것으로 기대된다. 또한 사라져가는 근현대사의 복 원 자료로서 활용가치가 높으며, 한국 근대사를 배경 으로 한 문화콘텐츠의 자료로 제공하여 활용가능할 것으로 생각된다.

\section{References}

Busan Modern History Museum. (2005). 都總 ['Dochong'=Sum all together]. Busan: Busan Modern History Museum.

Choi, E. J. (2015). A study of the shape and tailoring of frock coats in the Korean Empire: Park Ki- 
Jong's frock coat. The Research Journal of the Costume Culture, 23(3), 439-453. doi:10.7741/rjcc. 2015.23.3.439

Choi, K.-S. (2008). A study on court dress in Gungnaebu of Daehan empire. Korean Studies Quarterly, 31(2), 3-39.

Choi, K.-S. (2011). Preparation of the Japanese compulsory annexation of Korea appeared in the changed system of the western-style full dress uniform in 1905 1906. Journal of Korean Independence Movement Studies, 39, 5-45.

Choi, K.-S. (2012). 대한제국시대 관원의 예복 [The ceremonial costume of Daehan Empire]. In Kyungwoon Museum (Ed.), 대한제국 남성예복: 새로운 물결, 주체적 수용 [Men's robe in Korean Empire] (pp. 121-147). Seoul: Kyungwoon Museum.

Choi, Y. M. (1995). A study on the vest pattern of men in twenties related to roher index. Journal of the Korean Society of Clothing and Textiles, 19(6), 1008-1016.

Culture Heritage Administration. (2012). 2012 근 · 현 대문화유산 의생활분야 목록화 조사 보고서 [2012 a report of investigation in clothing habits contents for modern $\cdot$ present age]. Daejeon: Cultural Heritage Administration.

Davis, R. I. (1994). Men's garments, 1830-1900: A guide to pattern cutting and tailoring (2nd ed.). Studio City, CA: Players Press.

Fashion Text Dictionary Committee. (1999). 패션전 문자료사전 [Fashion text dictionary]. Seoul: Korean Dictionary Researcher.

Hwang, J. A. (2000). A Study on the changes of Korean costumes during the enlightenment period. Unpublished master's thesis, Sookmyung Women's University, Seoul, Korea.

Kim, D. C. (2005). 박기종 [Park Ki Jong]. In Busan Metropolitan City History Editorial Office (Ed.), (20 세기) 부산을 빛낸 인물 2 [Bring glory person in Busan at 20C, 2] (pp. 73-82). Busan: Busan Metropolitan City.

Kim, J. S. (1990). 한국양복100년사 [A hundred his- tory of western costume in Korea]. Seoul: Mirinae. Kim, M. J. (1977). 개화기의 문관복에 대한 연구 [The study of the changes on Government officials' garments of the Chosun days]. Journal of the Korean Society of Costume, 1, 67-84.

Kim, Y. H. (1987). A study on the introduction of western costume and the process of reception in the civilized age of Korea. Unpublished master's thesis, Sungkyunkwan University, Seoul, Korea.

Kim, Y. S. (1998). 한국복식문화사전 [A dictionary of Korean traditional apparel]. Seoul: Art Culture.

Korean Empire Ministry Record Section. (1982). 法规 類編: 2. 規制門 [Legal regulations edition: 2. Regulations]. Seoul: Asiamoonwhasa. (Original work Published 1908)

Kum, K. S., Kim, M. J., Kim, Y. I., Kim, Y. H., Park, M. H., Park, M. Y.,... \& Choi, H. J. (2002). 현대 패션 100년 [Fashion 1900-2000]. Seoul: Gyomoonsa.

Kyungwoon Museum. (2012). 대한제국 남성예복: 새 로운 물결, 주체적 수용 [Men's robe in Korean Empire]. Seoul: Kyungwoon Museum.

Lee, K. M. (1999). Comparison between the Korean and Japanese costume systems since port opening treaties in nineteenth century. Unpublished master's thesis, Seoul National University, Seoul, Korea.

Lee, K. M. (2008). Western-styled court costume paradigm of the Korean Empire. Unpublished doctoral dissertation, Seoul National University, Seoul, Korea.

Lee, K.-M. (2010). The institution of court costume in the year 1900 (the 4th year of Korean Empire Gwangmu) and the symbolism of Mugunghwa, the rose of sharon pattern. Journal of the Korean Society of Costume, 60(3), 123-137.

Lee, K.-M. (2011). A study on the revision and the loss of national identity of western-styled court costume in the Daehan Empire. Journal of Korean Society of Costume, 61(4), 103-116.

Lee, K.-M. (2013). A study on the construction of court dresses in the Daehan Empire: Focused on the 
coat pattern. Journal of the Korean Society of Costume, 63(6), 56-68. doi:10.7233/jksc.2013.63.6. 056

Lee, K.-M., \& Lee, S.-W. (2000). Comparison between the Korean and Japanese costume systems since port opening treaties in nineteenth century. Journal of the Korean Society of Costume, 50(8), 149-163.

Lee, S. H. (1984). The transformation of costume during the period of modernization of Korea and the factors. Unpublished master's thesis, Ewha Womans University, Seoul, Korea.

Lee, Y. J. (1996). 신사복 미학 [Aesthetics on men's wear]. Seoul: Fromm To.

Lee, Y. K., \& Kim, J. G. (1995). 우리나라 양복수용 과정의 복식변천에 대한 연구: 문화전파이론을 중심으로 [A study on the change of the process of western clothing adoption of Korea]. Journal of Korean Society of Costume, 26, 123-143.

Min Chulhoon. (n.d.). In Encylopedia of Korean culture. Retrieved January 20, 2017, from http://terms. naver.com/entry.nhn?docId $=555385 \&$ cid $=46623 \&$ categoryId $=46623$
National Place Museum of Korea. (2010). (100년 전 의 기억) 대한제국 [100 years past: Memories of the Korean empire]. Seoul: GraphicNet.

Park, S. S. (2003). 개화기 복식의 변천 [The transformation of costume during the period of modernization of Korea]. Dankook University Academy of Asian Studies, 295-310.

Ryu, H. K. (1980). 한국 복식사 연구 [Research of Korean costume history]. Seoul: Ewha Womans University Press.

Ryu, H. K. (1989). 한국복식문화사 [History of Korea Costume]. Seoul: Gyomoonsa.

Vest. (n.d.). In Naver Korean dictionary. Retrieved December 11, 2016, from http://krdic.naver.com/ detail.nhn?docid $=34168300$

Yun Chiho. (n.d.a). In Encylopedia of Korean Culture. Retrieved January 20, 2017, from http://terms. naver.com/entry.nhn?docId $=540398 \&$ cid $=46623 \&$ categoryId $=46623$

Yun Chiho. (n.d.b). In The digital local culture encylopedia of Korea. Retrieved January 20, 2017, from http://terms.naver.com/entry.nhn?docId=2570922 $\&$ cid $=51930 \&$ categoryId $=54216$ 